\title{
DAYA TERIMA WAJIT NANGKA SEBAGAI VARIAN WAJIT KHAS CILILIN BANDUNG BARAT
}

\author{
Sifa Miftahul Z, Ade Juwaedah ${ }^{1}$, Atat Siti Nurani \\ Program Studi Pendidikan Tata Boga, Departemen Pendidikan Kesejahteraan Keluarga, \\ Fakultas Pendidikan Teknologi dan Kejuruan, UPI \\ sifamiftahul@student.upi.edu
}

\begin{abstract}
Cililin memiliki beragam kuliner dan makanan yang khas, salah satu oleh-oleh atau makanan khas dari kecamatan Cililin yaitu wajit. Dari data hasil penjualan yang didapat bahwa penjualan wajit Cililin mengalami penurunan pada periode 2017-2018, dengan demikian perlu adanya inovasi terhadap produk oleh-oleh khas Cililin tersebut yaitu dengan memberikan varian rasa pada wajit dengan penambahan daging buah nangka beserta bijinya. Bandung Barat termasuk produksi nangka terbesar ke-4 di Jawa Barat. Tujuan penelitian ini untuk membuat resep wajit nangka dan menganalisis uji hedonik daya terima wajit nangka. Selain daging buahnya, biji nangka dapat dimanfaatkan menjadi bahan pengganti dari bahan utama wajit yaitu beras ketan karena biji nangka memiliki $83,73 \%$ amilopektin dan $16,23 \%$ amilosa. Tujuan penelitian ini adalah memanfaatkan produksi buah nangka yang di inovasikan dengan oleh-oleh khas Cililin yaitu wajit. Metode penelitian yang dilakukan adalah dengan metode eksperimental yaitu dengan menganalisis resep wajit Cililin dan mengambil sampel dari wajit merk "SR" untuk dilakukan uji sensori, selanjutnya melakukan uji coba produk wajit nangka sebanyak 2 kali. Dengan adanya penelitian ini, setelah melakukan QDA (Quantitative Descriptive Analisys) oleh 15 orang panelis semi terlatih, terdapat hasil kriteria wajit nangka warna cokelat gelap, rasa manis kuat, rasa gurih hampir lemah, aroma nangka tercium, aroma kelapa cukup tercium, aroma gula merah tercium dan tekstur yang cukup. Hasil uji hedonik wajit nangka dapat disimpulkan dari kesan keseluruhan bahwa 50\% panelis menyatakan suka dan $50 \%$ panelis menyatakan sangat suka pada produk wajit nangka.
\end{abstract}

Keyword: Daya terima, Cililin, Nangka, Wajit

\section{PENDAHULUAN}

Penelitian yang menjelaskan tentang foodscape dikemukakan oleh Norah Mackendrick pada tahun 2014 menjelaskan bahwa foodscape merupakan konsep lanskap yang diciptakan dari berbagai jenis makanan, seperti sayuran, buahbuahan, permen, coklat, kue, dan bahan-bahan lainnya yang banyak disukai dan sering dimakan, dengan mempertimbangkan tempat dan ruang dimana kita memperoleh makanan, menyiapkan makanan, berbicara tentang makanan, atau umumnya mengumpulkan makna dari makanan tersebut. Konsep ini berasal dari bidang geografi dan banyak digunakan dalam studi perkotaan, kesehatan masyarakat untuk merujuk pada lingkungan makanan perkotaan. Dalam hal Sosiologi telah memperluas konsep untuk memasukkan pengaturan kelembagaan, ruang budaya, dan wacana yang memediasi hubungan kita dengan makanan.

Kelompok-kelompok yang tertarik untuk menciptakan alternatif makanan yang menggunakan sistem distribusi makanan yang lebih demokratis dan melibatkan komunitas konsumen dengan nilai dan tujuan yang sama tumbuh sebagai tanggapan terhadap perusahaan foodscape organik. Kelompok-kelompok ini mengambil bentuk food policy councils (FPC) atau dewan kebijakan pangan, kebun masyarakat, koperasi pangan, dan pertanian yang didukung masyarakat. Ruang digital dan online 
merupakan komponen lain dari foodscape yang perlu mendapat perhatian lebih yaitu dengan cara membuat blog makanan dan aplikasi seperti Instagram (di mana konsumen mengunggah foto-foto hidangan yang mereka buat atau yang akan dikonsumsi). Memediasi hubungan kita dengan makanan kita dan tempattempat di mana kita mendapatkan makanan. Adanya aplikasi pembelian makanan online yang cukup hanya log-in dan klik "tambahkan ke keranjang".

Brianna Cameron mengemukakkan tentang flow food pada tahun 2016, menjelaskan bahwa flow food merupakan aliran/tahapan yang menggambarkan makanan pada saat memasuki tempat kerja hingga disajikan kepada pelanggan. Aliran/tahapan produk makanan Ini mengacu pada proses penerimaan, penyimpanan, persiapan, pemasakan, penahanan, penyajian, pendinginan, dan pemanasan ulang yang dilalui makanan di fasilitas layanan makanan. Setiap langkah dalam aliran makanan merupakan prosedur keamanan pangan yang umum harus diikuti untuk membantu mengurangi risiko kontaminasi dan penanganan yang salah dan dapat menyebabkan wabah penyakit bawaan makanan.

Terdapat 4 kriteria pembelian barang bahan makanan yang harus diperhatikan agar lebih efektif, diantaranya :

1. Pembelian yang efektif akan membuka jalan bagi operasi layanan makanan yang sukses. Pembelian adalah aktivitas berbasis keterampilan yang membutuhkan pengetahuan luas tentang produk dan kondisi pasar.

2. Pembelian melibatkan peroleh makanan dalam jumlah yang tepat, kualitas terbaik, pada waktu yang tepat, di tempat yang tepat, dan dengan harga paling ekonomis.

3. Program pengendalian kualitas di perusahaan jasa makanan harus memastikan bahwa hanya makanan yang memenuhi spesifikasi tertulis yang dibeli dari vendor terkemuka.

4. Pembeli yang baik mempertimbangkan harga, pasokan, dan permintaan, transportasi, dan biaya penyimpanan sebelum melakukan pemesanan.

Tujuan utama dari program pembelian yang efektif untuk membeli produk yang paling cocok untuk pekerjaan itu. Beli dengan jumlah yang tepat, bayar dengan harga yang tepat, dan hanya berurusan dengan pemasok yang memiliki reputasi dan dapat diandalkan. Spesifikasi pembelian penting bagi pembeli dan manajemen.

Makanan atau kue tradisional pengolahannya cenderung lama dengan menggunakan peralatanperalatan yang masih tradisional. Ada beberapa alasan mengapa kue tradisional kurang diminati, menurut Palupi (2010, hlm.1) menjelaskan bahwa komposisi bahan dan kandungan gizi tidak standar, waktu pngolahan lama, cara pengolahan tidak bersih, penyajian dan pengemasan kurang menarik, lokasi penyajian kurang nyaman, umur simpan pendek dan cita rasa kurang sesuai dengan selera generasi muda (Syarif dkk, 2019, hlm. 126). Berdasarkan permasalahan diatas, maka dapat dilihat bahwa jenis dan resep kue-kue tradisional merupakan salah satu aset dan nilai budaya yang 
mempunyai peranan penting, serta perlu dilestarikan dan dipertahankan.

Pada bulan Mei - Agustus 2016 di sejumlah pasar tradisional daerah Jabodetabek mengadakan program gerakan gebrak pasar. Gerakan peduli ini diharapkan merata keseluruh kalangan dimulai dari kaum perempuan, khususnya ibu-ibu, sebagai agen penggerak pelestari kuliner nusantara untuk lebih memperkenalkan jajanan manis khas Indonesia yang terkenal dengan cita rasanya. Fenomena yang terjadi saat ini adalah maraknya berbagai jajanan modern yang tersedia. Padahal kuliner Indonesia harus mendapatkan tempat yang sejajar, bahkan lebih tinggi dari jajanan populer lainnya yang berasal dari luar negeri.

Ada beberapa contoh makanan tradisional tersebut diantaranya Gulo Puan khas Palembang, Clorot khas Purworejo, Sayur Babanci khas Jakarta, Wajit khas Cililin dan sebagainya (Kosasih dkk, 2016, hlm. 2) .

Hasil penelitian dari Nurwitasari pada tahun 2015 tentang Pengaruh Wisata Gastronomi Makanan Tradisional Terhadap Keputusan Wisatawan Berkunjung ke Kota Bandung menjelaskan bahwa produk kuliner sebagai bagian dari wisata gastronomi Kota Bandung yang telah menjadi simbol penting bagi kepariwisataan Kota Bandung. Secara keseluruhan keputusan berkunjung wisatawan ke Kota Bandung termasuk pada kategori tinggi. Keputusan berkunjung ke Kota Bandung yang memperoleh penilaian tertinggi adalah pemilihan berdasarkan daya tarik produk wisata Kota Bandung. Sedangkan pemilihan jumlah kunjungan mendapat penilaian terendah. Hal ini menunjukan bahwa keberagaman serta keunikan produk wisata Kota Bandung menjadi daya tarik utama wisatawan ingin berkunjung ke Kota Bandung. Antara wisata gastronomi dengan keputusan berkunjung memiliki hubungan yang kuat. Hal ini menunjukan bahwa ketika wisata gastronomi dilaksanakan dengan baik, maka keputusan berkunjung wisatawan ke Kota Bandung pun akan cenderung bernilai positif.

Hasil penelitian dari Sormas, dkk tahun 2017 tentang Gastronomy in Tourism menjelaskan bahwa seorang turis mungkin ingin mengunjungi suatu daerah untuk mendapatkan pengalaman budaya baru, atau mereka hanya ingin mencoba hidangan lokal dan selera yang berbeda dari daerah itu juga. Sebagai akibatnya, alasan-alasan seperti mencoba hidangan lokal di suatu daerah dan mengamati fase produksi dan mencicipi hidangan lokal yang terbuat dari bahan baku yang hanya tersedia di wilayah tertentu sekarang mulai menjadi salah satu alasan utama yang mempengaruhi wisatawan untuk tempat tujuan yang dikunjungi. Pentingnya wisata gastronomi membantu reputasi perusahaan parawisata yang baik, serta menunjukkan bahwa konsumsi makanan dan minumn memiliki makna yang simbolis (tradisional). Dengan parawisata yang sukses meningkatkan kualitas populasi turis disuatu daerah dan memungkinkan dikunjungi setiap musim, sehingga menjaga warisan budaya dan memfasilitasi pembangunan ekonomi dan sosial budaya.

Salah satu makanan tradisional yang perlu dilestarikan adalah wajit khas Cililin, makanan yang terbuat dari hasil olahan beras ketan yang ditambahkan gula dan kelapa parut, disajikan dengan dibungkus menggunakan daun jagung kering. Wajit ini merupakan salah satu makanan khas Kecamatan Cililn dan menjadi usaha wajit di Kabupaten Bandung Barat, merupakan usaha industri skala kecil yang telah ada secara turun temurun dan masih bertahan hingga saat ini (Andarwati, 2012, hlm. 4).

Pada kenyataannya wajit khas Cililin mengalami penurunan pada volume penjualan. Hal ini dapat dilihat dari data survey yang dilakukan oleh 
penulis pada Maret 2019. Penulis melakukan survey pada 5 toko sentra penjual wajit yang mengalami penurunan, diantaranya (1) Toko "Cap Potret" mengalami penurunan sekitar 28\%, (2) Madu Rasa yaitu sekitar $18 \%$, (3) Pusaka yaitu sekitar $-27 \%$, (4) Sederhana yaitu sekitar $-26 \%$, (5) Seger Rasa yaitu sekitar $-21 \%$. . Maka dari itu, dari data diatas menunjukkan bahwa wajit Cililin mengalami penurunan hasil penjualan, dengan demikian perlu adanya inovasi terhadap produk oleh-oleh khas Cililin tersebut . Pengertian Inovasi menurut UU No. 18 tahun 2002, merupakan kegiatan penelitian, pengembangan, dan/atau perekayasaan yang bertujuan mengembangkan penerapan praktis nilai dan konteks ilmu pengetahuan yang baru, atau cara baru untuk menerapkan ilmu pengetahuan dan teknologi yang telah ada ke dalam produk atau proses produksi. Wajit Cililin yang akan penulis buat dengan diberi varian menggunakan buah nangka beserta bijinya.

Bandung Barat merupakan kabupaten yang memiliki panen buah nangka terbesar sekitar 44.583 kwintal setelah Majalengka, Bogor dan Cianjur (BPS, 2016). Dinas Pertanian Perkebunan dan Kehutanan Kab. Bandung Barat tahun 2012 menyebutkan sentra buah nangka di kabupaten Bandung Barat yaitu di Cisarua dengan 14434 kwintal, Gunung Halu dengan 10380 kwintal dan Cililin dengan 2050 kwintal (BPS, 2013).

Hasil penelitian oleh Kurniasih tahun 2016 pada Eksperimen Pembuatan Dodol Biji Nangka menjelaskan, biji nangka mengandung $83,73 \%$ amilopektin dan $16,23 \%$ amilosa. Tepung beras ketan mengandung karbohidrat $80 \%$ (dalam bentuk amilosa $1 \%$ dan amilopektin $99 \%$. Berdasarkan hal tersebut biji nangka mempunyai peluang sebagai bahan dasar pembuatan wajit sebagai pengganti beras ketan.
Sebagian besar masyarakat Batujajar Cililin menganggap bahwa biji nangka merupakan bahan yang sering terbuang begitu saja setelah daging buah nangka dikonsumsi. Beberapa orang ada yang memanfaatkan biji nangka untuk dikonsumsi dengan cara direbus atau pun dibakar. Biji nangka kebanyakan dibuang dan hanya beberapa masyarakat yang memanfaatkannya dengan direbus.

Biji nangka memiliki istilah dari daerah jawa dengan sebutan "beton". Karakteristik beton memiliki 83,73 amilopektin . Sifat amilopektin tersebut dapat digunakan dalam bahan pembuatan wajit. Maka dari itu, penulis telah melakukan uji coba pembuatan wajit nangka dengan proporsi biji nangka dalam formula resep wajit nangka.

Penelitian ini bertujuan untuk menemukan formula wajit nangka sebagai varian wajit khas Cililin dan hasilnya kemudian akan dianalisis tentang daya terima wajit nangka sebagai varian wajit khas Cililin.

\section{METODE}

Penelitian resep wajit nangka menggunakan metode eksperimental, dilaksanakan selama 5 bulan yaitu mulai April - Agustus 2019. Tahap penelitian yang dilakukan diantaranya (1) pengumpulan informasi teks melalui studi literatur tentang wajit, dari buku resep, skripsi, dan jurnal online yang menunjang dan relevan dengan permasalahan yang dibahas, untuk menemukan formula wajit keseluruhan. (2) Melakukan Focus Group Discussion (FGD) tentang indikator kenampakan wajit khas Cililin. Wajit yang digunakan sebagai rujukan adalah wajit "SR". Pelaksanaan FGD dilakukan oleh 15 panelis semi terlatih mahasiswa pendidikan tata boga 2015 dalam mengenali indikator wajit khas Cililin. Instrumen untuk FGD tentang 
kenampakan wajit khas Cililin menggunakan skala garis (line scale) dengan jenis uji organoleptik deskripsi. (3) Merancang formula resep wajit nangka melalui tahap:

1. Melakukan studi banding 3 resep wajit yang terdapat di buku sumber diantaranya yaitu dari buku Demedia Pustaka oleh Ayu Kharie, Gramedia Pustaka Utama oleh Siti Fatimah, Gramedia Pustaka oleh Andi Firlani, 2 resep online yaitu dari menuinternasional.com oleh Franciscus Didik dan cookpad.id oleh Elia Kurniawati.

2. Mencari resep wajit khas Cililin tradisi keluarga langsung dari pembuat wajit Cililin oleh pemilik toko "SR" dan pengrajin wajit home industry oleh ibu SA dan ibu N.

3. Melakukan studi perbandingan penggunaan bahan dan formula dari 8 resep yang penulis lakukan pada tahap (1) dan (2). Unsur yang menjadi fokus penelitian diantaranya bahan, jumlah masing-masing bahan (takaran), teknik memasak, dan teknik membungkus.

4. Membuat formula awal wajit nangka berdasarkan hasil pemikiran penulis.

(4) Penulis melakukan pembuatan produk wajit sesuai dengan rancangan yang telah ditetapkan. Dalam pelaksanaannya apabila masih terdapat perbaikan maka penulis akan membuat produk pengembangan sampai mendekati produk rujukan. (5) Penulis melakukan Quantitative Descriptive Analysis (QDA) terhadap produk yang dikembangkan kepada panelis semi terlatih yang terlibat dalam FGD sampai titik diterima. Produk pengembangan yang dianggap "jenuh kualitas" atau sesuai dengan resep wajit khas Cililin dijadikan sebagai resep standar oleh penulis. (6) Setelah melakukan uji coba produk pengembangan, selanjutnya hasil akhir wajit nangka yang sudah sesuai dengan produk rujukan dijadikan untuk uji hedonik kepada panel kosumen sebanyak 20 orang mahasiswa Universitas Pendidikan Indonesia dan 20 orang masyarakat sekitar daerah Batujajar-Cililin.

Dalam pengolahan data analisis statistika yang digunakan pada QDA dan uji hedonik yaitu menggunakan analisis dekstiptif dengan nilai ratarata. Pengolahan data yang pertama adalah pada QDA. Selanjutnya pengolahan data yang kedua dilakukan untuk pengolahan data uji hedonik, nilai akhir rata-rata QDA dapat dibaca dengan chart radar atau disebut dengan spider web dan nilai akhir rata-rata hedonik dapat dibaca dengan diagram batang atau disebut coloum chart.

\section{HASIL PENELITIAN}

Penulis menggunakan 15 orang panelis Mahasiswa Pendidikan Tata Boga 2015 untuk melakukan uji Focus Group Discussion (FGD). Pada 24 jam sebelum dilaksanakannya uji FGD produk wajit rujukan (Wajit "SR"), panelis harus melaksanakan pelatihan tentang kenampakan sensori wajit "SR" oleh penulis sebagai "pelatih". Indikator uji kenampakan sensori wajit rujukan diantaranya :

1. Identitas umum calon panelis

2. Uji pengenalan aroma dari calon panelis yang terdiri dari aroma gula merah dan parutan kelapa.

3. Uji pengenalan rasa dari calon panelis yang terdiri dari manis 
dan gurih

4. Uji pengenalan tekstur dari calon panelis yang terdiri dari berpasir dan tidak berpasir.

Berdasarkan seleksi panelis diatas hasilnya menunjukan semua calon memenuhi kriteria panelis yang ditetapkan penulis sesuai dengan kebutuh an penulis pada produk wajit Cililin dan wajit nangka produk pengembangan.

Tahap selanjutnya penulis membuat program FGD sebanyak 2 kali untuk mendapatkan deskripsi kenampakan organoleptik dari produk wajit Cililin merek SR yang dilakukan oleh 15 orang panelis terpilih yang sudah dilatih penulis. Hasil FGD yang di sepakati oleh panelis mendeskripsikan beberapa hasil kriteria karakteristik sensori pada wajit SR dengan atribut penampilan kategori warna cokelat dengan skor rata-rata 8,3 yaitu cukup cokelat, pada atribut rasa kategori manis dengan skor rata-rata 8,9 yaitu cukup, pada atribut rasa kategori gurih dengan skor rata-rata 4,05 yaitu hampir lemah, pada atribut aroma kategori kelapa dengan skor rata-rata 9,2 yaitu kuat, pada atribut aroma kategori gula merah dengan skor rata-rata 9,1 yaitu kuat, pada atribut tekstur kategori berpasir dengan skor 8,2 yaitu cukup berpasir.

Penulis menghimpun 8 resep wajit diantaranya 3 resep dari buku resep wajit yaitu dari buku Demedia PustakaAyu Kharie, Gramedia Pustaka Utama oleh Siti Fatimah, Gramedia Pustaka oleh Andi Firlani, 2 dari resep online yaitu dari menuinternasional.com oleh Franciscus Didik dan cookpad.id oleh Elia Kurniawati, 3 resep dari naraumber atau pengrajin wajit seperti bapak Samsul, Ibu Siti Aisyah dan Ibu Nuraeni. Berdasarkan dari hasil analisis 8 resep, terdapat 4 aspek yaitu bahan, jumlah bahan, proses pembuatan dan proses pembungkusan. Indikator rujukan untuk bahan wajit nangka yang dibuat oleh penulis merujuk pada proses pembuatan wajit Cililin terdapat ada perhitungan $70 \%$. Dari hasil analisis resep yang memiliki persentase $100 \%$ adalah beras ketan, gula aren, dan gula pasir merupakan bahan yang digunakan pada seluruh resep, sedangkan $80 \%$ menggunakan kelapa parut. Untuk teknik pengolahannya $100 \%$ beras ketan dikukus, proses pencairan gula merah (karamelisasi), adanya pencampuran bahan di atas wajan dengan api sedang, tunggu samapi adonan kalis dan keluar minyak agar tidak menempel pada wajan. Setelah adonan matang, tunggu selama 12 jam agar adonan benar-benar tidak menempel pada saat dibungkus. Pada saat wajit yang sudah jadi kemudian dijemur selama 24 jam. Kemasan wajit $80 \%$ menggunakan kulit jagung kering yang dibentuk segitiga ketika dibungkus.

Penulis membuat formula awal wajit nangka berdasarkan hasil pemikiran penulis, dengan resep sebagai berikut :

Bahan :

Beras ketan putih $\quad 50 \%$

Daging buah nangka bubur $100 \%$

Biji nangka (tanpa kulit) $\quad 100 \%$

Gula merah aren $\quad 80 \%$

Gula pasir $\quad 100 \%$

Garam meja $\quad 30 \%$

Kelapa parut $\quad 100 \%$

Proses pembuatan :

Untuk teknik pengolahannya beras ketan dikukus, proses pencairan gula merah (karamelisasi), penambahan daging buah nangka dan biji nangka 
yang sudah dilumatkan ke dalam wajan, adanya pencampuran bahan di atas wajan dengan api sedang, tunggu sampai adonan kalis dan keluar minyak agar tidak menempel pada wajan sekitar 2 jam. Setelah adonan matang, tunggu selama 12 jam agar adonan benar-benar tidak menempel pada saat dibungkus. Untuk wajit yang sudah matang kemudian dijemur selama 24 jam. Kemasan wajit menggunakan kulit daun pisang kering dengan ukuran lebar $15 \mathrm{~cm}$ dan panjang $12 \mathrm{~cm}$. Dari $300 \mathrm{gr}$ daun pisang kering direndam dengan air bersih selama 2 jam agar daun pisang menjadi lentur ketika dibentuk, kemudian olesi menggunkan minyak kelapa agar adonan wajit nangka tidak menempel. Untuk 1 pieces wajit dengan berat 30 gr.

Melalui uji coba resep wajit nangka secara mandiri sebelum melakukan QDA yang menurut penulis mendekati resep wajit Cililin, yaitu sebanyak 2 kali uji coba. Penelitian yang penulis lakukan terhadap produk wajit nangka dinyatakan berhasil menurut deskripsi dari hasil para panelis semi terlatih sehingga penulis mengambil resep uji coba ke-2 dengan adanya perubahan pada formula resep yaitu adanya penambahan pada kelapa parut, pengurangan takaran bahan gula merah, dan penambahan takaran bahan gula pasir. Dibawah ini merupakan gambar dan bahan pengemasan wajit nangka yang penulis buat :

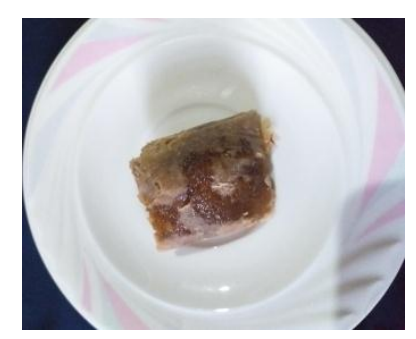

Sumber: Penulis

Gambar 1 Wajit Nangka

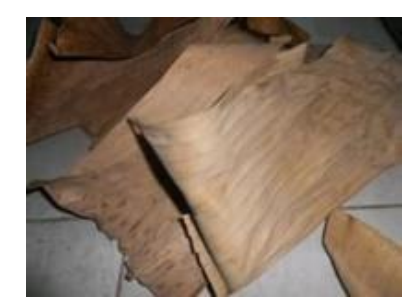

Sumber : Penulis

Gambar 2 Daun pisang kering sebagai bahan pengemasan

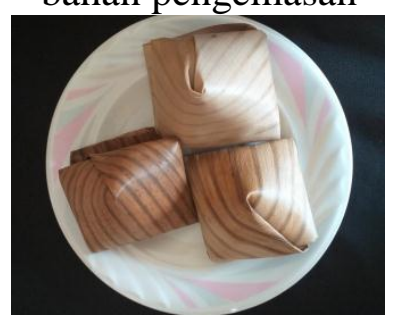

Sumber : Penulis

Gambar 3 Penampilan Wajit Nangka

Setelah melakukan uji coba ke-2 yang mendekati produk rujukan kemudian dilakukannya uji QDA (Quantitative Descriptive Analisys) oleh 15 orang panelis semi terlatih mahasiswa Tata boga 2015, maka terdapat beberapa hasil kriteria karakteristik sensori pada wajit nangka dengan atribut penampilan kategori warna cokelat dengan skor rata-rata 9 yaitu cukup cokelat, pada atribut rasa kategori manis dengan skor rata-rata 9 yaitu cukup, pada atribut rasa kategori gurih dengan skor rata-rata 4 yaitu hampir lemah, pada atribut aroma kategori kelapa dengan skor rata-rata 9,2 yaitu kuat, pada atribut aroma kategori gula merah dengan skor ratarata 9,1 yaitu kuat, pada atribut aroma kategori buah nangka dengan skor 11 yaitu kuat pada atribut tekstur kategori berpasir dengan skor 8,5 yaitu cukup berpasir.

Resep uji coba ke-2 yang menjadi pedoman untuk bahan uji hedonik kepada 40 orang panelis konsumen, 
diantaranya 20 orang mahasiswa di Universitas Pendidikan Indonesia dan 20 orang masyarakat umum daerah Cililin dan Batujajar. Untuk 1 resep menghasilkan 22 buah wajit nangka, masing-masing $\pm 30 \mathrm{gr} / \mathrm{buah}$.

Berdasarkan hasil uji hedonik didapatkan hasil sebegai berikut :

a. Hasil akumulasi uji hedonik untuk 40 panelis konsumen keseluruhan diantaranya 20 orang mahasiswa di Universitas Pendidikan Indonesia dan 20 orang masyarakat umum daerah Cililin dan Batujajar, dapat dilihat pada diagram berikut :

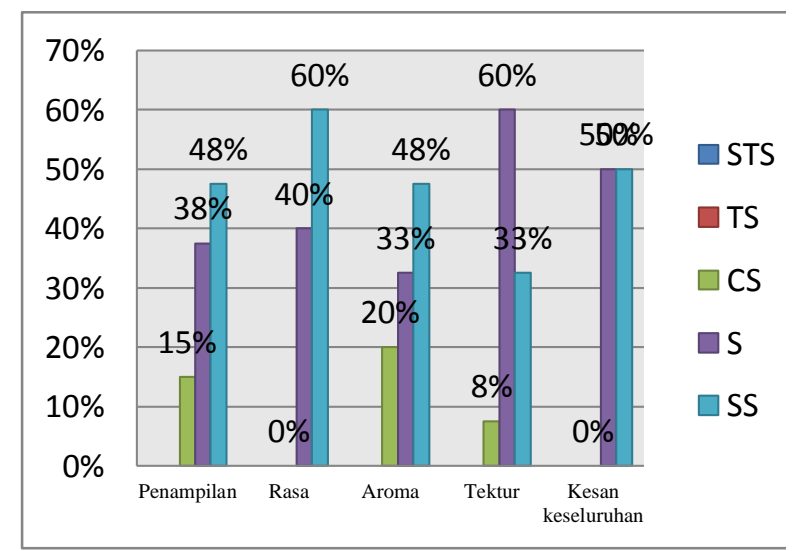

Gambar 4 Diagram chart hasil akumulasi keseluruhan uji hedonik wajit nangka

Berdasarkan pengolahan data hasil uji hedonik produk wajit nangka dapat dideskripsikan atribut sensori wajit nangka dari 40 panelis konsumen adalah sebagai berikut :

1. Untuk deskripsi atribut sensori pada aspek warna wajit nangka yaitu $48 \%$ panelis menyatakan sangat suka, $38 \%$ panelis menyatakan suka, $15 \%$ panelis menyatakan cukup suka, 0\% panelis menyatakan sangat tidak suka, $0 \%$ panelis menyatakan tidak suka. Sehingga dapat disimpulkan bahwa panelis menyukai warna wajit nangka .
2. Untuk deskripsi atribut sensori pada aspek rasa wajit nangka yaitu $60 \%$ panelis menyatakan sangat suka, $40 \%$ panelis menyatakan suka, 0\% panelis menyatakan sangat tidak suka, $0 \%$ panelis menyatakan menyatakan tidak suka, $0 \%$ panelis menyatakan cukup suka. Sehingga dapat disimpulkan bahwa panelis menyukai rasa wajit nangka nangka.

3. Untuk deskripsi atribut sensori pada aspek aroma wajit nangka yaitu $48 \%$ panelis menyatakan sangat suka, 33\% menyatakan suka, 20\% panelis menyatakan cukup suka, 0\% panelis menyatakan sangat tidak suka, 0\% panelis menyatakan menyatakan tidak suka. Sehingga dapat disimpulkan bahwa panelis menyukai aroma wajit nangka.

4. Untuk deskripsi atribut sensori pada aspek tekstur wajit nangka, $60 \%$ panelis menyatakan suka, 33\% panelis menyatakan sangat suka, $8 \%$ panelis menyatakan cukup suka, 0\% panelis menyatakan sangat tidak suka, $0 \%$ panelis menyatakan menyatakan tidak suka. Sehingga dapat disimpulkan bahwa panelis menyukai tekstur wajit nangka.

5. Untuk deskripsi atribut sensori pada aspek kesan keseluruhan wajit nangka yaitu, 50\% panelis menyatakan sangat suka, 50\% panelis menyatakan suka, $0 \%$ panelis menyatakan cukup suka, $0 \%$ panelis menyatakan sangat tidak suka, $0 \%$ panelis menyatakan menyatakan tidak suka. Sehingga dapat disimpulkan bahwa panelis menyukai wajit nangka berdasarkan kesan keseluruhan. 
a. Hasil uji hedonik kepada 20 mahasiswa UPI dapat dilihat pada diagram berikut ini :

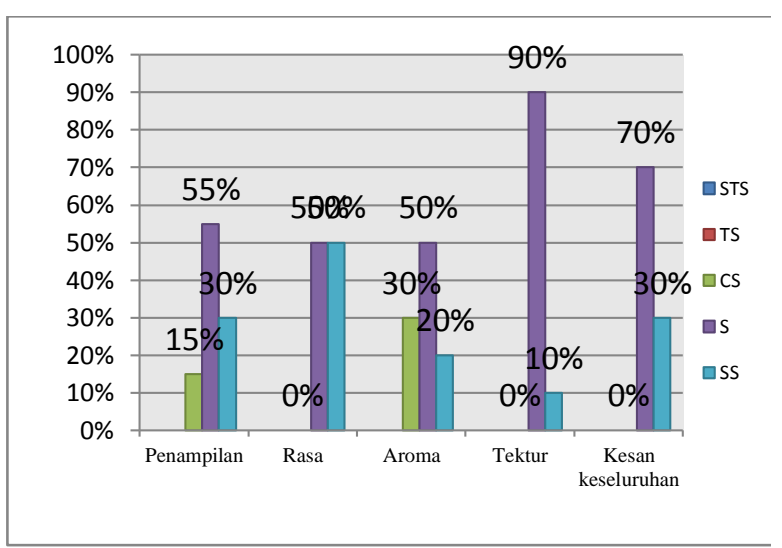

Gambar 5 Diagram chart hasil uji hedonik wajit nangka panelis konsumen mahasiswa UPI

Deskripsi atribut sensori wajit nangka dari 20 orang panelis konsumen mahasiswa UPI sebagai berikut :

1. Untuk deskripsi atribut sensori pada aspek warna wajit nangka yaitu $55 \%$ panelis menyatakan suka, 30\% panelis menyatakan sangat suka , $15 \%$ panelis menyatakan cukup suka, 0\% panelis menyatakan sangat tidak suka, $0 \%$ panelis menyatakan menyatakan tidak suka.

2. Untuk deskripsi atribut sensori pada aspek rasa wajit nangka yaitu, $50 \%$ panelis menyatakan sangat suka, 50\% panelis menyatakan suka, 0\% panelis menyatakan cukup suka, $0 \%$ panelis menyatakan sangat tidak suka, $0 \%$ panelis menyatakan menyatakan tidak suka.

3. Untuk deskripsi atribut sensori pada aspek aroma wajit nangka yaitu, $50 \%$ panelis menyatakan suka, 30\% panelis menyatakan cukup suka, 20\% panelis menyatakan sangat suka, 0\% panelis menyatakan sangat tidak suka, 0\% panelis menyatakan menyatakan tidak suka

4. Untuk deskripsi atribut sensori pada aspek tekstur wajit nangka, 90\% panelis menyatakan suka, $10 \%$ panelis menyatakan sangat suka, $0 \%$ panelis menyatakan cukup suka, $0 \%$ panelis menyatakan sangat tidak suka, $0 \%$ panelis menyatakan menyatakan tidak suka.

5. Untuk deskripsi atribut sensori kesan keseluruhan wajit nangka yaitu, $70 \%$ panelis menyatakan suka, 30\% panelis menyatakan sangat suka, $0 \%$ panelis menyatakan cukup suka, 0\% panelis menyatakan tidak suka, $0 \%$ panelis menyatakan sangat tidak suka.

b. Hasil uji hedonik kepada 20 masyarakat umum di daerah Cililin dan Batujajar dapat dilihat pada diagram berikut :

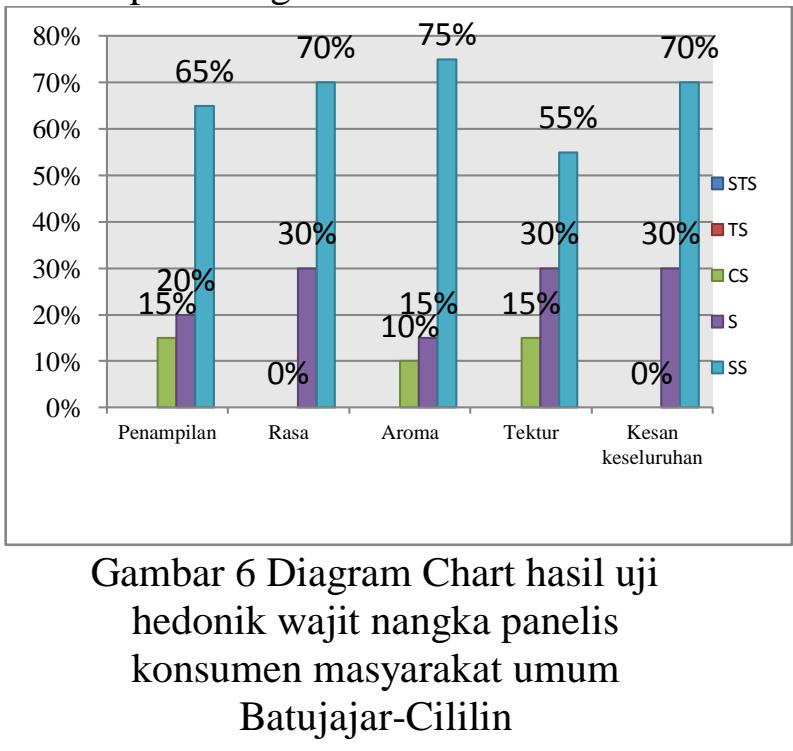

Deskripsi atribut sensori wajit nangka dari 20 orang panelis konsumen masyarakat umum Batujajar-Cililin sebagai berikut :

1. Untuk deskripsi atribut sensori 
pada aspek warna wajit nangka yaitu $65 \%$ panelis menyatakan sangat suka, $20 \%$ panelis menyatakan suka, $15 \%$ panelis menyatakan cukup suka, $0 \%$ panelis menyatakan sangat tidak suka, $0 \%$ panelis menyatakan menyatakan tidak suka.

2. Untuk deskripsi atribut sensori pada aspek rasa wajit nangka yaitu, $70 \%$ panelis menyatakan sangat suka, $30 \%$ panelis menyatakan suka, 0\% panelis menyatakan cukup suka, $0 \%$ panelis menyatakan menyatakan tidak suka, $0 \%$ panelis menyatakan sangat tidak suka.

3. Untuk deskripsi atribut sensori pada aspek aroma wajit nangka , 75\% panelis menyatakan sangat suka, $15 \%$ menyatakan suka, $10 \%$ panelis menyatakan cukup suka, $0 \%$ panelis menyatakan sangat tidak suka, 0\% panelis menyatakan menyatakan tidak suka.

4. Untuk deskripsi atribut sensori pada aspek tekstur wajit nangka yaitu, 55\% panelis menyatakan sangat suka , 30\% panelis menyatakan suka, $15 \%$ panelis menyatakan cukup suka, 0\% panelis menyatakan sangat tidak suka, 0\% panelis menyatakan menyatakan tidak suka.

5. Untuk deskripsi atribut sensori kesan keseluruhan wajit nangka yaitu, $70 \%$ panelis menyatakan sangat suka, $30 \%$ panelis menyatakan suka, 0\% panelis menyatakan cukup suka, 0\% panelis menyatakan menyatakan tidak suka, $0 \%$ panelis menyatakan sangat tidak suka.

\section{PEMBAHASAN}

Kue tradisional merupakan wujud hasil budaya warisan para leluhur bangsa, yang di pelajari secara turuntemurun. Secara spesifik di daerah atau masyarakat Indonesia, biasanya kue tradisional diolah dari resep yang sudah dikenal masyarakat setempat dengan bahan-bahan yang di peroleh dari sumber lokal yang memiliki citarasa yang relatif sesuai dengan selera masyarakat setempat. Kue tradisional dikenal pula dengan istilah kudapan dan penganan. Kue Nusantara dapat berfungsi sebagai makanan selingan atau makanan jajanan yang umunya dihidangkan disela-sela waktu makanan utama.

Menurut Marlina Sembiring (2014, hlm. 1) mengatakan bahwa di Indonesia kue tradisional disebut juga sebagai jajanan Indonesia, karena secara tradisional kue ini banyak di jajakan di pasar tradisional. Hasil olahannya berupa kue, olahan rumah rumah tangga atau pun industri yang menyajikan atau dikonsumsi sebagai makanan selingan, sarapan atau sebagai makanan pembuka atau penutup. Makanan atau kue tradisional pengolahannya cenderung lama dengan menggunakan peralatanperalatan yang masih tradisional. Ada beberapa alasan mengapa kue tradisional kurang diminati.

Menurut Palupi (2010, hlm.1) menjelaskan bahwa komposisi bahan dan kandungan gizi tidak standar, waktu pngolahan lama, cara pengolahan tidak bersih atau hygienis, penyajian dan pengemasan kurang menarik, lokasi penyajian kurang nyaman, umur simpan pendek dan cita rasa kurang sesuai dengan selera generasi muda (Syarif dkk, 2019, hlm. 126). 
Wajit yang biasa di kenal masyarakat luas adalah wajit yang berasal dari ketan atau wajit ketan. Wajit ketan terbuat dari beras ketan yang dikukus kemudian dimasak dengan campuran santan, gula hingga berminyak dan terasa lembut. Gula yang digunakan pada wajit jenis ini biasanya adalah gula merah. Gula merah yang digunakan akan membuat wajit menjadi berwarna cokelat muda hingga cokelat tua. Setelah wajit diangkat dari tempat pengolahan, wajit kemudian dibentuk atau diiris sesuai dengan keinginan pembuat. Bentuk yang biasa dibuat adalah bentuk belah ketupat atau jajar genjang. Bentuk belah ketupat atau jajar genjang oleh orang Jawa biasa disebut bentuk wajit, oleh karena itu kue ini bernama wajit. Kue wajit biasanya juga berbau harum karena dalam pengolahannya menggunakan daun pandan (Misela, 2017).

Wajit adalah kue yang dibuat dari campuran beras ketan, gula Jawa atau pasir yang dicampur parutan kelapa atau santan kemudian dipotong-potong seperti segi empat atau kotak-kotak.Wajit sendiri ternyata termasuk dalam kategori makanan atau camilan zaman Majapahit. Hal ini tertulis dalam kitab nawaruci. Kitab Nawaruci merupakan karya sastra yang berbahasa Jawa Tengah yaitu bahasa yang muncul pada jaman kejayaan Majapahit. Kitab Nawaruci atau Sang Hyang Tattawajnana ditulis antara tahun 1500-1619 Masehi oleh Empu Siwamurti. Kitab Nawaruci ini merupakan karya sastra religius yang terpengaruh ajaran mistik Hindu.

Makanan tersebut menjadi sebuah simbol yang menurut adat istiadat sangat perlu untuk dijadikan serangkaian prosesiprosesi pada pernikahan. Makanan yang harus ada pada prosesi pernikahan menurut adat jawa adalah makanan yang terbuat dari beras ketan. Beras ketan setelah dimasak akan memiliki sifat lengket. Dalam tahap kedua di pernikahan, daun pisang, daun pandan, beras, dan kelapa adalah beberapa bahan yang harus selalu ada dan berfilosofi.
Tanaman ini melambangkan harapan, kemakmuran, kesuburan, dan kesatuan yang diharapkan setelah membangun keluarga baru. Dari filosofi sifat dan tujuan dalam tahapan - tahapan upacara adat Jawa, makanan yang berasal dari beras ketan ini dijadikan simbol sebagai pelekat, dimana menandakan bahwa semoga kedua pengantin dan antar keluarga memiliki kedekatan yang harmonis. Serta menandakan tujuan dari tahap pertama yaitu mengakrabkan anggota mempelai baik orang tua, keluarga besar dan mempelai itu sendiri (Agustine, dkk, 2017).

Adapun beberapa jenis wajit (Sunda)/ Wajik (Jawa) berdasarkan daerahnya :

1. Wajit ketan

2. Wajit bandung

3. Wajit kletik

4. Wajit khas Cililin

Karakteristik wajit Cililin menurut bapak Samsul sebagai pengrajin wajit, menjelaskan bahwa :

1. Wajit terasa manis legit dan gurih.

2. Tekstur wajit diluar keras dan didalamnya lembut (semi basah).

3. Tekstur kelapa terasa.

4. Dibungkus dengan klobot/daun jagung kering.

Berikut bahan pembuatan wajit nangka :

1. Beras ketan yang dpilih yaitu IR64 adalah yang berwarna putih susu dan tidak transparan, butiran berasnya yang masih utuh dan tidak patah. Beras ketan tersebut didapatkan di Borma Leuwigajah.

2. Kelapa yang diguanakan adalah kelapa tua usia 9 bulan, didapatkan dari tempat tinggal peneliti di desa Laksanamekar.

3. Gula yang digunakan adalah gula aren didapatkan dari pasar 
Batujajar.

4. Gula pasir, jenis gula yang berasal dari cairan tebu kemudian dikristalkan, sari tebu akan mengalami kristalisasi dan berubah menjadi butiran gula yng berwarna putih dan berwarna agak kecokelatan (raw sugar).

5. Buah nangka yang digunakan adalah buah nangka bubur yang sudah matang tua. Daging nangka tidak terlalu matang/lembek dan masih keras.

Bandung Barat merupakan kabupaten yang memiliki panen buah nangka terbesar sekitar 44.583 kwintal setelah Majalengka, Bogor dan Cianjur (BPS, 2016). Dinas Pertanian Perkebunan dan Kehutanan Kab. Bandung Barat tahun 2012 menyebutkan sentra buah nangka di kabupaten Bandung Barat yaitu di Cisarua dengan 14434 kwintal, Gunung Halu dengan 10380 kwintal dan Cililin dengan 2050 kwintal (BPS, 2013).

Biji nangka berbentuk bulat dan lonjong, berukuran kecil kurang lebih $3,5 \mathrm{~cm}$ (3 gram- 9 gram), berkeping dua dan rata-rata buah nangka yang berisi biji beratnya sepertiga dari berat buah, sisanya adalah kulit dan daging buah. Jumlah biji perbuah sekitar 150- 350 biji dan panjang nangka sekitar $3,5 \quad \mathrm{~cm}-4,5 \quad \mathrm{~cm}$ (Dennis, 2017, hlm. 8).

Ditinjau dari komposisi kimianya biji nangka mengandung pati cukup tinggi, yaitu sekitar $40-50 \%$, sehingga sangat berpotensi sebagai sumber pati (Pangesthi, 2014, hlm 1). Biji nangka mengandung $83,73 \%$ amilopektin dan $16,23 \%$ amilosa. Tepung beras ketan mengandung karbohidrat $80 \%$ (dalam bentuk amilosa $1 \%$ dan amilopektin 99\%). Berdasarkan hal tersebut biji nangka mempunyai peluang sebagai bahan dasar pengganti tepung beras ketan (Irwansyah, 2010).

Maka dari itu, produk pengembangan yang penulis buat berupa wajit nangka dengan bahan utama yaitu beras ketan putih, gula merah, gula pasir, kelapa parut, daging buah nangka dan bijinya, dilihat dari hasil data keseluruhan uji hedonik menyimpulkan bahwa wajit nangka sebagai varian wajit khas Cililin dapat diterima oleh kalangan masyarakat dan mahasiswa UPI. Ada beberapa keunggulan pada wajit nangka yang penulis buat , diantaranya :

1. Adanya inovasi terhadap wajit khas Cililin dimana saat ini terjadi fenomena penurunan volume penjualan.

2. Wajit dapat diberi variasi rasa dengan tambahan daging buah nangka beserta bijinya.

3. Menguatkan model wajit yang sudah ada.

4. Meningkatkan pemanfaatan biji nangka.

5. Menjadi potensi untuk mendongkrak pasar internasional.

6. Adanya subtitusi beras ketan dengan biji nangka, selain untuk menghemat juga sebagai alternatif bahan utama.

7. Dilihat dari segi foodscape, wajit nangka dapat di ubah menjadi satu hidangan yang unik dan menarik agar dapat di publikasikan kepada para konsumen terutama dalam packaging/pengemasan.

\section{KESIMPULAN}

Secara umum dapat disimpulkan bahwa olahan buah nangka bisa dijadikan sebagai varian rasa pada wajit. Tidak hanya daging buah nangka 
saja, biji nangka dapat dijadikan sebagai bahan pengganti beras ketan karena biji nangka memiliki kandungan $83,73 \%$ amilopektin dan 16,23\% amilosa. Pada uji coba wajit nangka dilakukan sebanyak 2 kali uji coba, hasil terakhir yang dipilih oleh 15 semi terlatih adalah uji coba ke-2 sebagai produk yang sesuai dengan wajit rujukan yaitu wajit "SR". Bahan utama wajit nangka diantaranya adalah beras ketan, gula merah aren, gula putih, biji nangka, daging buah nangka dan kelapa parut .

Setelah melakukan QDA (Quantitative Descriptive Analisys) oleh 15 orang panelis semi terlatih mahasiswa Tata boga 2015, terdapat beberapa hasil kriteria dari wajit nangka dengan warna cokelat gelap, rasa manis kuat, rasa gurih hampir lemah, aroma nangka tercium, aroma kelapa cukup tercium, aroma gula merah tercium dan tekstur yang cukup.

Setelah melakukan uji hedonik kepada 40 orang panelis konsumen yang terdiri dari 20 orang mahasiswa yang masih berstatus aktif sebagai mahasiswa Universitas Pendidikan Indonesia di lingkungan kampus UPI Setiabudi dan 20 masyarakat umum rentang usia 20-45 tahun di daerah Cililin dan Batujajar dapat disimpulkan dari kesan keseluruhan bahwa 50\% panelis menyatakan suka dan 50\% panelis menyatakan sangat suka pada produk wajit nangka .

\section{REFERENSI}

BPS. (2013). Kabupaten Bandung Barat Dalam Angka 2013. Bandung Barat: Badan Pusat Statistik Kabupaten Bandung Barat.

BPS. (2016). Kabupaten Bandung Barat Dalam Angka 2016.
Bandung Barat: Badan Pusat Statistik Kabupaten Bandung Barat.

Kosasih, dkk. (2016). Rancang Bangun Aplikasi Makanan Khas Jawa Barat dengan Metode Interpolation Search Berbasis Android: Jurnal Teknik Informatika, 2-3.

Dewi, K. (2016). Eksperimen Pembuatan Dodol Biji Nangka (Artocaprus Heterophyllus) Dengan Penambahan Tepung Beras ketan yang Berbeda. (Tesis). Fakultas Teknik, Universitas Negeri Semarang, Semarang.

Ist. (2018). Sepenggal Sejarah dari Wajit Cililin. [Online]. Diakses dari

http://www.balebandung.com/sepeng gal-sejarah-dari-wajit-cililin/

Kusuma. (2011). Cara Memilih Beras Ketan Putih. [Online]. Diakses dari

http://hidanganbunda.blogspot.com/2 011/12/cara-memilih-beras-ketanputih.html

Nurwitasari, A. (2015). Pengaruh Wisata Gastronomi Makanan Tradisional Terhadap Keputusan Wisatawan Berkunjung ke Kota Bandung. (Skripsi). Sekolah Tinggi Pariwisata Bandung, 2.

Andaka, dkk. (2015). Pemanfaatan Limbah Biji Nangka sebagai Bahan Alternatif dalam Pembuatan Tempe. Jurnal Institut Sains \& Teknologi AKRIND Yogyakarta.

Utomo,dkk. (2016). Pemanfaatan Limbah Biji Nangka Menjadi Dodol dan Kerupuk. Universitas Yudharta Pasuruan, Sekolah Tinggi Teknologi Nurul Jadid Probolinggo, 7. 
Sormas,dkk. (2016). Gastronomy in Tourism. Journal Procedia Economics and Finance, 39.

Sarioglan. (2014). New Orientations in Gastronomy Education: Molecular Gastronom, journal Social and Behavioral Sciences, 143.

Tarwendah, dkk. (2017). Studi Komparasi Atribut Sensori dan Kesadaran Merek Produk Pangan. Jurnal Pangan dan Agroindustri Vol.5 No.2:66-73

Madyaratry. (2017). Analisis Profil Sensori Beras Siger Dengan Menggunakan Metode Quantitative Descriptive Analysis (QDA). (Skripsi). Fakultas Pertanian, Universitas Lampung, Bandar Lampung.

Mackendrick. (2014). Foodscape (Artikel) . SAGE. American SociologicalAssociation. 